3 rd and gth of February, and as a matter of fact in that period there were 58 cases, of which 46 were in the two regiments from the South, particularly susceptible to cold, with specially poor sanitary discipline, markedly neglectful of the sanitary regulations, and, as we know, with the least ventilated tents.

After the second "norther" a spell of fine weather closed the month. The other regiments lived outside their tents, aired them, and sumed their bedding and equipment, while the chilly southerners still huddled into their tents, and in the correlated period for the development of cases, from February 7 th to I4th, 68 cases occurred in the two regiments, 4.2 per cent., but only I7 (.I5 per cent.) among the other II,OOO soldiers in camp.

The infantry reformed on the 8 th February, the cavalry on the 24 th, but there had been no cold weather after the r 7 th. Still there had been a couple of days of cold weather on IIth and rath. This found the infantry ventilating themselves, the cavalry still unrepentant. The effect of the IIth and I2th should appear between the 23rd and 26th. The infantry $(I, 200 \mathrm{men})$ had $I 6$ cases, the negligent cavalry $(I, 200)$ had 59 cases.

The infantry regiment had in all 133 cases, the cavalry 203. It must, however, be allowed that the cavalry regiment, very anxious to learn its more troublesome drill, had been worked extremely hard before the epidemic, and was thus more worn down than the other regiment. Each of these corps had about 45 cases of measles to every roo soldiers reported as not having had measles, the percentage in other regiments was $5 \frac{1}{2}$.

Measles is a serious disease in the U.S. Army, showing a high death-rate. Eight of these cases got pnetrmonia and four of them died, whereas there were in the camp I5 other pneumonia cases out of which only one died. Besides that, the only three cases of cerebrospinal meningitis in the camp were in convalescent measles cases. The death-rate of the epidemic was .5 per cent. of cases, very low, thought to be due to early hospitalisation, preventing waste of strength.

It will be agreed that Colonel Munson has made out a strong case for the prevention of respiratory disease by ventilation, and for planning the prophylaxis of measles just as if it were a respiratory disease. To prevent measles consider it an acute respiratory disease, very infectious in the three days before the rash appears, and treat an early case in fresh or the open-air to prevent infection, as anxiously as you would a case of open tubercle of the lung for example, forbidding spitting and mixing with other people. Early isolation prevents spread of infection and reduces the death-rate.

It would appear we should regard measles as Dr. Ricketts taught us to regard small-pox, as a specific fever followed by a focal rash. The fever of small-pox is characterised by the prodromal rashes, that of measles by catarrh and coryza and Koplikis Spots. It is a pity the precise date from rash to rash in a case of undoubted direct transmission has not been stated, probably it is $\mathrm{I}_{4}$ days as in small-pox.

The military medical officer will note the clearness of Colonel Munson's demonstration that it pays a colonel better to have a few men off parade doing sanitary work, than to have full parades to begin with, but his regiment later off parade altogether with scores of men going to hospital because hygiene was neglected.

And in conclusion we have to thank Colonel Munson for so excellent a description of the measures he took to prevent measles, and of the obstacles he found in his path.

\section{TYPHOID FEVER SPREAD BY CHRONIC CARRIERS.}

A Report of Several Smali OUtbreaks of WHICH THREE WERE MILK BORNE.*

$I^{N}$ order to emphasize the importance of the typhoid carrier in the distribution of the infection through the hatdling of food, we have thought it might be of interest to add the cases which follow to the literature of this subject, and we shall first briefly describe a millk-borne epidemic in which the typhoid bacillus was isolated from the stool of a typhoid carrier on the dairy farm, and also from the milk which produced the outbreak of typhoid fever.

In rgI2, Stokes and Stonert observed 56 cases of typhoid, during July, August, September, and October, in a town of 2,500 inhabitants, and $5^{\circ}$ cases were found on the milk route of one milkman furnishing $I, 500$ persons, while the four other milkmen who served about $\mathrm{I}, 000$ persons had only 6 cases on their dairy routes. A further investigation disclosed the fact that a woman in the dairy who had been handling the milk and dispensing it to customers had suffered from typhoid. fever two years previously. An examination showed that

*By WM. Royax Stokes, M.D., Chief of Bureau of Bacteriology, Maryland State and Baltimote City, Departments of Health, and F. W. HACHIEI, M.D., Assistant Bacteriologist, Baltimore, Md., Department of Health, U.S.A.

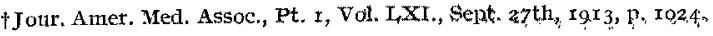


the fæces from this woman contained the typhoid bacillus. A later study of the milk for the presence of the typhoid bacillus resulted in the isolation of an organism which in all respects resembled the typhoid bacillus. The various confirmatory tests consisted of morphology and staining properties, cultural characteristics, agglutination tests with positive blood and immune typhoid serum, complement fixation tests, and bactericidal tests.

During the past few years the departments of health of Baltimore and of Maryland have investigated a number of typhoid outbreaks, which studies entailed the examination of specimens from a number of people for the detection of carriers and resulted in the finding of several of these.

The first of these outbreaks consisted of a series of 22 cases which were traceable to milk. Connected with the handling of this milk was a woman who had had enteric fever about one year previously. An examination of specimens of her stool and urine demonstrated the presence of typhoid bacilli in both. No other carriers were detected among the other people employed at this dairy.

Another outbreak occurred in a college with about 600 students, of whom approximately from 200 to 300 were exposed to the source of infection, a lunch room that had in its employ a cook who was later found to be a typhoid carrier. Of those exposed to this source of infection, II developed enteric fever within a period of one month. After the discovery and removal of the carrier no other cases occurred.

Another outbreak was traced to a woman 75 years old, who had had typhoid fever in September, Igr2. Before she entirely recovered, her granddaughter, living in the same home, developed typhoid fever, and while the latter case was recovering, this patient's two-year-old son developed typhoid fever, and later died of this disease. In May, I9I3, the older woman's son-in-law contracted typhoid fever and his daughter developed this disease in the latter part of July, I9I6. A child aged I3 developed typhoid fever in November, I9I6, and all of these three later cases were confirmed by the Widal reaction. In November, I9I6, a boy aged 9 and a mariied woman who obtained their milk from the dairy of the original case, developed typhoid fever. Upon further investigation it was found that her son-in-law and his three children had been drinking milk which had been obtained from the dairy of the motherin-law, being the original case.

In analyzing the above circumstances it would seem that the case of the grand-daughter and a great-g1andson of the original case might have been a house outbreak, although they very probably drank milk which was handled by the original case. The other cases wotuld seem to be due to milk furnished by the original case, since an examination of the stools made five years after the attack of typhoid showed the presence of numerous typhoid bacilli.

In two oiher house outbreaks we found that there had been three cases of typhoid fever within a period of three years in one family, and upon examining the stool of the father of the household, who had had typhoid fever five years previously, we found the typhoid bacillus. In another case in which several members of the household had developed typhoid fever within a period of three years we found the typhoid bacillus in the stool of one of several sisters. Neither of these typhoid carriers cooked or handled food as far as we could learn, and it is difficult to trace out the exact method of causation of these cases.

The next investigation was that of four cases of enteric fever occurring in one family over a period of several months. This resulted in the discovery that the servant was a carrier, $B$. typhosus being isolated from his urine. In the course of the investigation specimens from the drainpipes of several refrigerators were sent to the department, and from one of these an organism which culturally resembles the typhoid bacillus was isolated. This bacillus is also agglutinated by the blood of typhoid cases and by typhoid immune serum. Further studies of this organism are being made, and will be reported later by one of the authors. Il is interesting to note that this organism was isolated from the material from the waste pipe of the pantry refrigerator, which could readily have become contaminated by the servant. In addition to the above-mentioned cases another was traceable to this same man. This was the servant's grandson who lived with his grandfather.

Another familial outbreak studied consisted in all of three cases out of a family of six persons. The first was the mother of the family, followed four months after her recovery by her husband and four years later by her daughter. Fæces and urine of both father and mother were examined in the course of the investigation, and the stool of the latter was found to contain typhoid bacilli.

In another family four cases of enteric fever occurred over a period of four or five years. During the investigation suspicion was directed toward the cook by the following facts: She had lived with these people at the time of the first two cases, but later on left them for a peiod of two or thiee years, during which time no case developed in this household. Almost immediately upon her return to the family in capacity of cook, the other two cases developed. The examination of her urine and fæces resulted in the detection of $B$. typhosus in the latter. This woman denied having had typhoid, bu: has had several severe attacks of biliary colic. - Public Health Reports, Washington, U.S.A. 